\title{
As an Educator, The Evaluation of the Competences of Coaches from the Point of View of the Elite Athletes: The Case of Elite Taekwondo Athletes
}

\author{
Melih Nuri Salman \\ Correspondence: Melih Nuri Salman, Aksaray University, Sport Science Faculty, Turkey. \\ Received: May 26, 2019 \\ doi:10.11114/jets.v7i9.4289 \\ Accepted: June 30, 2019 Online Published: July 4, 2019 \\ URL: https://doi.org/10.11114/jets.v7i9.4289
}

\begin{abstract}
This study was aimed at identifying the perceptions and assessments of elite taekwondo athletes toward coaching efficacy. The purposeful sample consisted of 77 elite taekwondo athletes who took part in Turkish national teams, won prizes in Turkish championships or prspective promising athletes. The research data were gathered by using the "Athletes' Assessment of Coaching Efficacy Questionnaire", a 5-point Likert type questionnaire that comprises 26 questions and was adjusted to Turkish and developed by Salman (2012) based on the "Coaching Confidence Questionnaire" developed by Feltz et al. (1999). The Cronbach's alpha coefficient of the questionnaire was .967. The study used the Kaiser-Meyer-Olkin (KMO) and Barlett's test to explain the suitability of the research data for explanatory factor analysis, and the Kaiser-Meyer-Olkin (KMO) value was found .907 . To analyze the data, $t$ test, One-way ANOVA and Tukey's test were performed. No significant difference was found between the groups for coaching efficacy belief based on age group and training age ( $>0.05)$. There was a significant difference in favor of men in all dimensions in relation to gender $(\mathrm{p}<0.05)$. As for sports career and national team participation, the study found a significant difference between the all groups $(\mathrm{p}<0.05)$. According to the results of the study, the athletes expressed their coaches were sufficient in terms of technique and strategy while they had some deficiencies in character building and motivation.
\end{abstract}

Keywords: elite athlete, coach, coaching efficiency, taekwondo

\section{Introduction}

\subsection{Introduce the Problem}

Taekwondo is a sport that consists of self-defense and strike techniques applied with hands and feet, and contributes to promoting ethical values in athletes. It is national sports of Korea, a far eastern country. Taekwondo was born and developed in this country, and spread throughout the world over time. The history of this discipline dating back to the early $13^{\text {th }}$ century goes back to the development of a defense system comprising foot techniques, called "Taek Kyon" (Foot System), by Korean people to defend themselves against all kinds of threats. It is also known that a system called "Kwonpop" (Fist Fighting Method) with only hand techniques was used for self-defense purposes in Korea in the same period. Warriors responsible for protecting the lands ruled by Silla Kingdom, the smallest of the three kingdoms in Korean peninsula in 600s, developed the abovementioned foot and hand techniques as a systematic means of combat in addition to various weapons, and called it Taek Kyon, which was later started to be referred to as Taekwondo. It is a compound word comprising three words (Hyo 1992, Karanfilci 2013). Its lexical meaning is as follows: TAE means foot and KWON means hands while DO refer to a way of thinking and behavior that must be adopted to achieve morality and virtue. Today, taekwondo is known as one of the oldest martial arts in the world.

Taekwondo recognition as a competitive sports date back to 1905. In 1966, representatives from 208 countries came together to establish the International Taekwondo Federation. Taekwondo appeared as a demonstration sport at the 1988 Olympic games in Seoul (WTF, 1995). It became an official sport at the 2000 Sydney Olympics. Originating as a far eastern sport, taekwondo is a popular sports discipline today practiced by more than 40 million people in over 150 countries worldwide (Türkmen, 2004). There are about 400 thousand registered athletes in Turkey practicing this sport that is based on far eastern self-defense, strike and discipline. Turkey Taekwondo Federation is among top 5 national federations in terms of the number of medals won at the Olympic games and World Championships while it is the third federation with the highest number of athletes after football and chess (Sports Statistics, 2018).

The achievements of representatives of Turkish Taekwondo national teams in World Championships are also remarkable. 
In 16 World Championships between 1983 and 2017, Turkish athletes won third place 29 times, second place 12 times and first place 13 times. When we look at the past four Olympic Games (2000 Sydney, 2004 Athens, 2008 Beijing, 2012 London and 2016 Rio), we see that Turkish athletes secured third place 3 times (1in men's and 2 in women's category), second place 3 times ( 1 in men's and 2 in women's category), and won championship in men's category once Servet Tazegül, Londra 2012.

Taekwondo training is built on the principle of modesty in social behaviors. The virtues of bravery and modesty are based on self-confidence. It is obvious that a healthy body makes a person energetic and strong. Physical and mental training enhanced with self-confidence helps individuals become useful in daily life, family environment and society at large (Kim, 1975). The primary characteristic of taekwondo as a self-defense art is that not only it provides an opportunity for practitioners to protect themselves at maximum level but also enhances self-confidence in them. There are numerous scientific studies on the long-term effects of taekwondo on practitioners. Many of them are cross-sectional studies exploring sporting career of athletes or how long they have been doing this sport. An analysis of the results of these studies indicated that athletes practicing taekwondo went through positive psychosocial changes (Duthie, Hope \& Barker, 1978, Rothpearl, 1980; Nosanchuk, 1981, Nosanchuk \& Mac Neil, 1989; Skelton et al., 1991; Kurian et al., 1993, Kim, 1995, Kim et al. 2011, Tadesse 2016, Benke at al. 2017, Petrovic 2017).

Having major sports achievements in international sports has become extremely difficult nowadays for athletes' motor skills, etc. are very similar (Ziv \& Lidor 2009, Ghobadi, at al, 2013). Today, high performance and success in sports comes not only with physical, technique and tactical training, but also with psychological preparation and organization of social life. Therefore, performance in sports is a whole and it is necessary to achieve harmony within this wholeness (Konter, 2006). Such harmony must be greatest in the relationship between coach and athlete. Mallet (2007), states that sport environment is a complex one requiring exclusive effort to understand as the web of relationships between coach, athlete and training has a dynamic social structure.

Developments in sports science has resulted in higher sportive performance in taekwondo as in all sports disciplines and come into more prominence in such factors as increase in training time, mental training, competition analysis and communication skills, etc. As a natural consequence of these developments, time spent by the coach and athlete together has increased. The relationship and harmony between the coach and athlete as well as self-development and updating of the coach have gained greater significance for athletes to display high performance. Considering the surrounding circle of athletes in sports environment, it is recognized that relationship with the coach is the biggest factor affecting their performance (and hence, determining their sports career). Here, it is the duty of coaches first to provide high motivation for developing and maintaining a technique, tactical and game approach by acting in harmony with athletes, and to maximize athlete performance.

Coaches are supposed to perform all these tasks properly by knowing their responsibility for high performance of athletes in every aspect. Thus, coaches who organize efforts to make each athlete feel special, to contribute to their development in technique and tactical aspects and to remedy their individual deficiencies, and transform such effort into personal and team achievement are accepted as accomplished coaches in their environment. All these characteristics must come to the fore among required qualifications of a coach. It was found that when coaches were asked to evaluate themselves, they mentioned having the abovementioned qualities adequately (Konter, 1996). Many scientific studies on self-assessment of coaches obtained similar results (e.g. Chelladurai \& Saleh 1980, Gleeson 1987, Feltz, Chase, Moritz \& Sullivan 1999, Cote at all.1999, Chelladurai 2007, Toros \& Duvan 2011, Tomczak, Kaczarek \& Komar 2017). "Coaching Behavior Scale for Sport (CBS-S)" developed by Cote, Yardley, Hay, Sedgwick \& Baker (1999) are among major studies on this subject. However, it was found that there are few studies in the relevant literature on how athletes see their coaches, and how they evaluate their coaching skills in terms of technique, tactical approach, motivation and implementation skills as well as character building.

This study was conducted to investigate how elite Turkish taekwondo athletes evaluates the skills of their coaches in line with their own views and ideas. The study also sought to determine the level of coaching efficacy by identifying the strengths and weaknesses of the coaches in enhancing individual performance.

\section{Method}

\subsection{Participant}

A total of 77 elite taekwondo athletes (27 women and 50 men) who were selected as the purposeful sample of taekwondo practitioners in Turkey participated in the study. The group consisted of 77 elite taekwondo athletes who took part in Turkish national teams, won prizes in Turkish championships or promising athletes 


\subsection{Data Collection and Data Collection Tolls}

The research data were gathered by using a 5-point Likert type questionnaire with 26 questions asking athletes to evaluate their coaches. The questionnaire was developed and adjusted to Turkish by Salman (2012) based on the "Coaching Confidence Questionnaire", a 9-point Likert type questionnaire with 24 questions, developed by Feltz et al. (1999) to ask coaches to assess themselves. The "Athletes' Assessment of Coaching Efficacy Questionnaire" consists of two parts with 31 questions in total. The first part includes five questions about descriptive statistical information to obtain personal data on the participants. The second and main part of the questionnaire comprises 26 questions to measure coaching efficacy. Scoring on the 5-point Likert type questionnaire is as follows: 'strongly agree' (5), 'agree' (4), 'neither agree nor disagree' (3), 'disagree' (2) and 'strongly disagree' (1). The lowest score to be obtained on the questionnaire is 26 and highest score is 130 . The range of the 5-point scale is 5-1=4 while the calculated interval coefficient is $(4 / 5=80)$. The scoring range of the questionnaire is as follows: strongly disagree (1.00-1.80), disagree (1.81-2.60), neither agrees nor disagree (2.61-3.40), agree (3.41-4.20) and strongly agree (4.21-5.00).

\subsection{Validity and Reliability Issues}

The Cronbach's alpha coefficient is .978 for the whole questionnaire, and .967 in the reliability test conducted on the four dimensions (motivation, strategy, technique and character building). This value indicates that internal consistency of the questionnaire is satisfying. The Kaiser-Meyer-Olkin (KMO) and Barlett's tests were used to explain the suitability of the study group data for explanatory factor analysis. The results are shown in Table 1.

Table 1. KMO and Barlett's test results for the suitability of the athletes' assessment of coaching efficacy questionnaire for factor analysis

\begin{tabular}{lll}
\hline Kaiser-Meyer-Olkin (KMO) & .907 \\
\hline Bartlett's Test of Sphericity & Chi-square & 2657.356 \\
\cline { 2 - 3 } & & \\
\cline { 2 - 3 } & $\mathrm{Sd}$ & 325 \\
\hline \multirow{2}{*}{ Cronbach's Alpha } & Sig & 0.00 \\
& Whole Scale $\quad(\mathrm{p}<0.05)$ & .978 \\
& 4 Dimensions $(\mathrm{p}<0.05)$ & .967 \\
\hline
\end{tabular}

Field (2009) maintains that the acceptable value for the Kaiser-Meyer-Olkin test must be KMO $<0.50$ or otherwise, the factor analysis cannot be completed. Çokluk (2012) and Karaalioğlu (2015) indicate that if this value is higher, each variable on the scale can be predicted accurately by other variables. The Kaiser-Meyer-Olkin (KMO) value was .907 in this study.

Table 2. Arithmetic mean, standard deviation and variance analysis results for the dimensions

\begin{tabular}{|c|c|c|c|c|}
\hline & $\mathrm{Sd}$ & Eigen $v$. & $\begin{array}{l}\text { Percent } \\
\text { Variance }\end{array}$ & $\begin{array}{l}\text { Total Percent } \\
\text { Variance }\end{array}$ \\
\hline Factor 1 (motivation) & $3.92 \quad .81$ & 17.130 & 65.884 & 65.884 \\
\hline Factor 2 (strategy) & $4.26 \quad .90$ & 1.534 & 5.901 & 71.785 \\
\hline Factor 3 (technique) & $4.26 \quad .92$ & 1.107 & 4.258 & 76.042 \\
\hline Factor 4 (character building) & 3.94 & 1.042 & 4.008 & 80.050 \\
\hline
\end{tabular}

As is shown in Table 2, arithmetic mean, standard deviation and variance of the dimensions were calculated separately in analyzing the data obtained from the study group, and the variables were compared based on all the dimensions. The study dimensions were determined as motivation (Factor 1), strategy (Factor 2), technique (Factor 3) and character building (Factor 4). While Factor 1 explained $65.884 \%$ of total variance, factor 2 explained $5.901 \%$, factor $34.258 \%$ and factor $44.008 \%$. The four dimensions comprising the questionnaire and distribution of the questions according to these dimensions are as follows: motivation $(1,3,6,10,12,15,23,25)$, strategy $(2,4,8,9,11,17,21)$, technique $(7,14,16,18,20,22)$ and character building $(5,13,19,24,26)$. 


\subsection{Data Analysis}

Based on the gender variable, data on motivation, strategy, technique and character building, dimensions were analyzed through $\mathrm{T}$ test. One-way ANOVA was used for multiple variables such as age, sporting career, national team participation and training age, etc. Also Tukey's test was administered to determine the source of differences between the variables as result of the analyses. SPSS 21.0 software was used to analyze the data, and the level of significance for statistical procedures was set at $\mathrm{p}<0.05$.

\section{Results}

Table 3. Demographic characteristics of the study group

\begin{tabular}{|c|c|c|c|c|c|c|c|}
\hline & & $\mathrm{n}$ & $\%$ & & & $\mathrm{n}$ & $\%$ \\
\hline & 15-19 years old & 17 & 22.1 & & & & \\
\hline & 20-24 years old & 38 & 49.4 & & Female & 27 & 35.1 \\
\hline & 25-29 years old & 18 & 23.4 & & & & \\
\hline \multirow[t]{4}{*}{ Age } & $30+$ years old & 4 & 5.1 & \multirow{4}{*}{ Gender } & Male & 50 & 64.9 \\
\hline & Total & 77 & 100.0 & & & & \\
\hline & $1-5$ times & 19 & 247 & & Total & 77 & 1000 \\
\hline & 6-10 times & 15 & 19.4 & & Iotal & 11 & 100.0 \\
\hline \multirow{6}{*}{$\begin{array}{l}\text { Participation in } \\
\text { National Team }\end{array}$} & $11-15$ times & 7 & 9.1 & \multirow{9}{*}{$\begin{array}{l}\text { Training } \\
\text { Age }\end{array}$} & $1-5$ & & \\
\hline & $16+$ times & 18 & 23.4 & & years & 8 & 10.4 \\
\hline & Not National Athlete & 18 & 23.4 & & & & \\
\hline & National Athlete & 40 & 51.9 & & $\begin{array}{l}6-10 \\
\text { years }\end{array}$ & 25 & 32.5 \\
\hline & Junior National & 8 & 10.4 & & $11-15$ & & \\
\hline & Cadet National & 8 & 10.4 & & years & 32 & 41.6 \\
\hline \multirow[t]{3}{*}{ Sporting Career } & T. Championship $1,2,3^{\text {rd }}$ & 8 & 10.4 & & & & \\
\hline & Not National Athlete & 13 & 16.9 & & $\begin{array}{l}16+ \\
\text { years }\end{array}$ & 12 & 15.6 \\
\hline & Total & 77 & 100.0 & & Total & 77 & 100.0 \\
\hline
\end{tabular}

This study was conducted on 77 elite taekwondo athletes in Turkey. $35.1 \%$ of the participants were female while $64.9 \%$ were male. $51.9 \%$ of the athletes took part in a national team. $10.4 \%$ were member of the junior national team and $10.4 \%$ were in the cadet national team, whereas $10.4 \%$ won the top three prizes in Turkish championships. The rate of participants who were not selected to national team, but promising athletes was $16.9 \%$. As for athletes in national teams, $24.7 \%$ competed as a national athlete 1-5 times, $19.5 \%$ 6-10 times, 9.1\% 11-15 times, and $23.4 \% 16$ times or more. The distribution of the participants in age groups was as follows: $22.1 \%$ were between $15-19$ years old, $49.4 \%$ between 20-24 years old, $23.4 \%$ between $25-29$ years old and 5.2\% were 30 years or older. As for training age of the study group, it was found that $10.4 \%$ did taekwondo for $1-5$ years, $32.5 \%$ for $6-10$ years, $41.6 \%$ for $11-15$ years and $15.6 \%$ for 16 years or more. 
Table 4. ANOVA results for the dimensions based on age variable

\begin{tabular}{lcccccc}
\hline Dimension & Age Group & $\mathrm{n}$ & & $\mathrm{Sd}$ & $\mathrm{F}$ & Sig. \\
\hline \multirow{4}{*}{ Motivation } & $15-19$ & 17 & 3.98 & .86 & .245 & .865 \\
& $20-24$ & 38 & 3.92 & .81 & & \\
& $25-29$ & 18 & 3.94 & .86 & & \\
Strategy & 30 and above & 4 & 3.59 & .76 & & \\
& $15-19$ & 17 & 4.49 & .75 & 1.359 & .262 \\
& $20-24$ & 38 & 4.24 & .88 & & \\
Technique & $25-29$ & 18 & 4.25 & 1.03 & & \\
& 30 and above & 4 & 3.50 & .94 & & \\
\hline \multirow{4}{*}{ Character } & $15-19$ & 17 & 4.52 & .69 & 1.055 & .373 \\
Building & $20-24$ & 38 & 4.17 & .98 & & \\
& $25-29$ & 18 & 4.33 & 1.02 & & \\
& 30 and above & 4 & 3.70 & .82 & & \\
& $15-19$ & 17 & 4.07 & .62 & .770 & .514 \\
& $20-24$ & 38 & 3.93 & .69 & & \\
& $25-29$ & 18 & 3.95 & .70 & & \\
& 30 and above & 4 & 3.50 & .74 & &
\end{tabular}

According to Table 4, the study found no statistically significant difference between the groups for all dimensions (motivation, strategy, technique and character building) in relation to age group ( $\mathrm{p}>0.05)$.

Table 5. ANOVA results for the dimensions based on training age

\begin{tabular}{lllllll}
\hline Dimension & Tr. Age (Years) & $\mathrm{n}$ & $\mathrm{Sd}$ & & $\mathrm{F}$ & Sig. \\
\hline \multirow{4}{*}{ Motivation } & $1-5$ & 8 & 4.28 & .62 & .685 & .564 \\
& $6-10$ & 25 & 3.90 & .84 & & \\
& $11-15$ & 32 & 3.91 & .87 & & \\
& $16+$ & 12 & 3.75 & .74 & & \\
Strategy & $1-5$ & 8 & 4.69 & .69 & 1.526 & .215 \\
& $6-10$ & 25 & 4.28 & .92 & & \\
& $11-15$ & 32 & 4.29 & .84 & & \\
Technique 1 & $16+$ & 12 & 3.84 & 1.05 & & \\
& $1-5$ & 8 & 4.75 & .64 & 1.146 & .337 \\
& $6-10$ & 25 & 4.20 & .95 & & \\
Character & $1-15$ & 32 & 4.29 & .94 & & \\
Building & $16+$ & 12 & 3.98 & .94 & & \\
& $1-5$ & 8 & 4.25 & .60 & \multirow{2}{*}{1.485} & .226 \\
& $6-10$ & 25 & 4.06 & .64 & & \\
& $11-15$ & 32 & 3.86 & .66 & &
\end{tabular}

Table 5 indicates that no statistically significant difference was observed between the groups for any of the dimensions in relation to training age variable $(\mathrm{p}>0.05)$. 
Table 6. T test results for the dimensions based on gender variable

\begin{tabular}{lllllll}
\hline Dimension & Gender & $\mathrm{n}$ & $\mathrm{Sd}$ & & $\mathrm{F}$ & Sig. \\
\hline Motivation & Male & 50 & 4.190 & .65 & 8.936 & .004 \\
& Female & 27 & 3.780 & .86 & & \\
\hline Strategy & Male & 50 & 4.576 & .60 & 12.807 & .001 \\
& Female & 27 & 4.094 & .98 & & \\
\hline Technique & Male & 50 & 4.592 & .64 & \multirow{2}{*}{13.294} & .000 \\
& Female & 27 & 4.086 & 1.01 & & \\
\hline Character & Male & 50 & 4.163 & .53 & 6.050 & .016 \\
Building & Female & 27 & 3.828 & .72 & & \\
\hline
\end{tabular}

The study found a statistically significant difference between female and male participants in favor of men for all dimensions of the questionnaire based on gender $(p<0.05$, Table 6$)$. According to this result, male athletes found their coaches more successful in motivation, strategy, technique and character building compared to the female athletes.

Table 7. ANOVA results for dimensions based on sporting career

\begin{tabular}{|c|c|c|c|c|c|c|c|}
\hline Dimension & Ranking/Sport Career & $\mathrm{n}$ & $\mathrm{Sd}$ & & $\mathrm{F}$ & Sig. & Difference \\
\hline \multirow{5}{*}{ Motivation } & (1) National & 40 & 4.18 & .65 & 6.344 & .000 & $1>5$ \\
\hline & (2) Junior & 8 & 3.96 & .87 & & & $2>5$ \\
\hline & (3) T.C. $1,2,3^{\text {rd }}$ & 8 & 3.82 & .68 & & & $4>5$ \\
\hline & (4) Cadet & 8 & 4.09 & .99 & & & \\
\hline & (5) Not National & 13 & 3.04 & .68 & & & \\
\hline \multirow{5}{*}{ Strategy } & (1) National & 40 & 4.53 & .64 & 7.575 & .000 & $1>5$ \\
\hline & (2) Junior & 8 & 4.36 & .99 & & & $2>5$ \\
\hline & (3) T.C. $1,2,3^{\text {rd }}$ & 8 & 4.11 & .98 & & & $4>5$ \\
\hline & (4) Cadet & 8 & 4.66 & .68 & & & \\
\hline & (5) Not National & 13 & 3.23 & .93 & & & \\
\hline \multirow{5}{*}{ Technique } & (1) National & 40 & 4.54 & .65 & 5.712 & .000 & $1>5$ \\
\hline & (2) Junior & 8 & 4.41 & .99 & & & $2>5$ \\
\hline & (3) T.C. $1,2,3^{\text {rd }}$ & 8 & 4.14 & .99 & & & $4>5$ \\
\hline & (4) Cadet & 8 & 4.39 & 1.06 & & & \\
\hline & (5) Not National & 13 & 3.29 & .97 & & & \\
\hline \multirow{5}{*}{$\begin{array}{l}\text { Character } \\
\text { Building }\end{array}$} & (1) National & 40 & 4.17 & .58 & 5.859 & .000 & $1>5$ \\
\hline & (2) Junior & 8 & 4.00 & .61 & & & $4>5$ \\
\hline & (3) T.C. $1,2,3^{\text {rd }}$ & 8 & 3.70 & .61 & & & \\
\hline & (4) Cadet & 8 & 4.07 & .60 & & & \\
\hline & (5) Not National & 13 & 3.27 & .67 & & & \\
\hline
\end{tabular}

In relation to sporting career of the elite taekwondo athletes, the study found a statistically significant difference between the groups for all dimensions $(\mathrm{p}<0.05$, Table 7$)$. It was seen that athletes who were not a national team member considered their coaches were less sufficient in the area of motivation compared to the athletes in national, junior national and cadet national teams. The group with the highest coaching efficacy belief for their coaches in the area of game strategy was athletes in the cadet national team $(\bar{x}=4.66 \pm .68)$. It was followed by the group of athletes in the national team $(\overline{\mathrm{x}}=4.53 \pm .64)$. It was also found that athletes who had not joined national team yet had the lowest coaching efficacy belief for their coaches in the area of game strategy $(\overline{\mathrm{x}}=3.23 \pm .93)$. On the other hand, athletes in the cadet national team had highest coaching efficacy beliefs for their coaches in terms of strategy $(\overline{\mathrm{x}}=4.66 \pm$. 68$)$. 
Accordingly, it was concluded that there was a statistically significant difference between all national athletes except those in the cadet national team, and non-national athletes in favor of the national athletes $(p<0.05)$. Also the results for technique efficacy of the coaches were not different from the results on motivation efficacy between the groups $(\mathrm{p}<0.05)$. As for character building, a significant difference was observed between the athletes in the national team and cadet national team and non-national athletes $(\mathrm{p}<0.05)$.

Table 8. ANOVA results for the dimensions based on national team participation (N.T.P.)

\begin{tabular}{|c|c|c|c|c|c|c|c|}
\hline Dimension & N. T. P. & & $\mathrm{n}$ & $\mathrm{Sd}$ & $\mathrm{F}$ & Sig. & Difference \\
\hline \multirow{5}{*}{ Motivation } & (1) $1-5$ & 19 & 4.36 & .46 & 6.796 & .000 & $1>5$ \\
\hline & (2) $6-10$ & 15 & 3.92 & .88 & & & $2>5$ \\
\hline & (3) $11-15$ & 7 & 4.19 & .50 & & & $3>5$ \\
\hline & (4) $16+$ & 18 & 4.07 & .81 & & & $4>5$ \\
\hline & (5) None & 18 & 3.20 & .74 & & & \\
\hline \multirow{5}{*}{ Strategy } & (1) $1-5$ & 19 & 4.75 & .59 & 8.162 & 000 & $1>5$ \\
\hline & (2) $6-10$ & 15 & 4.40 & .73 & & & $2>5$ \\
\hline & (3) $11-15$ & 7 & 4.53 & .47 & & & $3>5$ \\
\hline & (4) $16+$ & 18 & 4.38 & .75 & & & $4>5$ \\
\hline & (5) None & 18 & 3.39 & 1.01 & & & \\
\hline \multirow{5}{*}{ Technique } & (1) $1-5$ & 19 & 4.69 & .68 & 5.989 & .000 & $1>5$ \\
\hline & (2) $6-10$ & 15 & 4.41 & .74 & & & $2>5$ \\
\hline & (3) $11-15$ & 7 & 4.50 & .50 & & & $3>5$ \\
\hline & (4) $16+$ & 18 & 4.40 & .87 & & & $4>5$ \\
\hline & (5) None & 18 & 3.45 & 1.03 & & & \\
\hline & (1) $1-5$ & 19 & 4.29 & .46 & 7.860 & .000 & $1>5$ \\
\hline Character & (2) $6-10$ & 15 & 4.09 & .62 & & & $2>5$ \\
\hline \multirow{3}{*}{ Building } & (3) $11-15$ & 7 & 4.31 & .25 & & & $3>5$ \\
\hline & (4) $16+$ & 18 & 3.93 & .66 & & & $4>5$ \\
\hline & (5) None & 18 & 3.32 & .65 & & & \\
\hline
\end{tabular}

The study identified a statistically significant difference between the groups for all dimensions based on national team participation of the athletes $(\mathrm{p}<0.05$, Table 8$)$. The group with the highest coaching efficacy belief for their coaches in the area of motivation was the group of athletes who were national team members $1-5$ times $(\bar{x}=4.36 \pm .46)$, whereas the group with the lowest efficacy beliefs about their coaches were those who had not participated in national team yet $(\overline{\mathrm{x}}=3.20 \pm .74)$. In the area of motivation efficacy, there was a statistically significant difference between non-national group and all other groups $(\mathrm{p}<0.05)$. The group of athletes with 1-5 times participation in national team had the highest efficacy beliefs for their coaches in the area of game strategy $(\bar{x}=4.75 \pm .59)$. This group was followed by the group of athletes with 11-15 times national team participation $(\overline{\mathrm{X}}=4.53 \pm .47)$, group of athletes with 6-10 times national team participation $(\overline{\mathrm{X}}=4.40 \pm .73)$ and those who represented national team 16 times or more $(\overline{\mathrm{X}}=4.38 \pm .75)$, respectively. National athletes considered their coaches were sufficient in the area of game strategy, whereas non-national athletes said their coaches were moderately sufficient in this regard. In the area of technique efficacy, there was a statistically significant difference between the group of winners of 1,2 and $3^{\text {rd }}$ prizes in Turkish championships and all national athlete groups, and those who were not in a national team $(\mathrm{p}<0.05)$. A significant difference was also found between the group of non-national athletes and all the other groups in relation to coaching contribution to character building $(\mathrm{p}<0.05)$.

\section{Discussion}

Based on age groups and training age of the participants, no statistically significant difference was found between the groups for any of the dimensions of motivation, strategy, technique and character building ( $>0.05$, Table 4 and 5). In the assessment between male and female athletes in relation to gender, there was a statistically significant difference in favor of men for all the dimensions ( $<<0.05$, Table 6). This result is similar to the result of a study conducted by Hodges and Carron (1992) to examine the effects of gender on self-efficacy scores of women and men doing individual and team sports. The present study demonstrated that male and female taekwondo athletes, in a shared understanding, gave high points to their coaches in the areas of technique and strategy efficacy. The high mean scores of the coaches in these dimensions was considered as a natural consequence of that coaches focused on technique training and instructed intense training towards constant development of tactical approach in preparation for competitions. While the athletes stated their coaches were sufficient in the areas of technique and game strategy, they stressed the coaches were lacking in some aspects in the areas of character building and motivation and had lower efficacy in these areas.

The fact that the coaches had high efficacy in technique and strategy according to the national athletes based on sporting career can be explained as that these athletes were trained by most experienced, knowledgeable coaches both in their clubs and national teams. This view is supported with the finding that athletes winning the $1^{\text {st }}, 2^{\text {nd }}$ and $3^{\text {rd }}$ prizes in 
Turkish championships thought their coaches had acceptable efficacy in technique and strategy while non-national athletes believed their coaches were moderately sufficient in these areas. As for character building and motivation, the national athletes and athletes winning the top three prizes in Turkish championships found their coaches acceptably sufficient and non-national athletes saw their coaches moderately sufficient in both dimensions, which indicates that all the coaches failed, regardless of level, in satisfying the expectations of the athletes fully in the areas of character building and motivation while they prioritized technique and game strategy.

In relation to participation in national team, the study found that the primary group with high efficacy beliefs toward their coaches for all dimensions was young athletes who were newly elected to national team (1-5 times). Having just started to participate in national team, these athletes believed their club coaches and coaches helping them to join national team played a significant role in their sporting achievement and hence, they had higher satisfaction in this regard, which may be considered as a result of being at the beginning of national athlete career. It was also found that the athletes participating in national team 11-15 times considered their coaches had high efficiency in the areas of technique, strategy and character building, and those participating in national team 6-10 times, 16 times or more saw their coaches were highly sufficient in the areas of strategy and technique; whereas, they believed the coaches had lower and acceptable efficiency in the areas of character building and motivation. This finding can be interpreted that athletes assessed their coaches more positively depending on increased international experience, knowledge and age. In their study, Dolaşır (2006) and Yurt (2009) reported that comments on coaching efficacy differed based on athlete age. The results of their study were similar to the results of the present study in this regard.

Lees and Shedden (1987) defined sports coaching as a very complex and complicated process. Underlining the major role of coaches in the development of sports and athletes, Serpa (1999) stressed the influence of coaches on most of the qualities acquired by athletes. While coaches usually see themselves sufficient in every area in athlete training, the fact that athletes sometimes have a different opinion in that regard should not be ignored. In fact, this study revealed that the coaches did not satisfy the expectations of the athletes in terms of character building and motivation. Increasing the number and duration of lessons introducing the mentioned qualities and skills within coaching training program starting from level 1 to 5 may prove effective in eliminating negative factors in this regard. Therefore, it will be useful to give particular importance to providing training by experts in this area in training seminars and courses to be held by the federation in addition to increasing the number and duration of relevant lessons. Only thus will it be possible to remedy the deficiencies of coaches in the areas of character building and motivation.

\section{References}

Behnke, M., Tomczak, M., Kaczmarek, L. D., Komar, M., \& Gracz, J. (2017). The Sport Mental Training Questionnaire: Development and Validation, Current Psychology, 1-13. https://doi.org/10.1007/s12144-017-9629-1

Chelladurai, P. (2007). Leadership in sports, in: Tenenbaum, G. and Eklund, R.C., ed., Handbook 14 of Sport Psychology, 3rd edit, John Wiley \& Sons, New York, 2007, 113-135.

Chelladurai, P., \& Saleh, S. D. (1980). Dimensions of leader behaviour in sports: development of a leadership scale. Journal of Sport Psychology, 2, 34-45. https://doi.org/10.1123/jsp.2.1.34

Côté, J., Yardley, J., Hay, J., Sedgwick, W., \& Baker, J. (1999). An exploratory examination of the coaching behaviour scale for sport. Avante, 5, 82-92.

Dolaşır, S. (2006) Antrenör etiği ve ilkeleri, Gazi Kitapevi, Ankara. ISBN: 9799756009092

Duthie, R. B., Hope, L., \& Barker, D. G. (1978). Selected personality traits of martial artists as measured by the adjective checklist. Perceptual and Motor Skills, 47, 71-76. https://doi.org/10.2466/pms.1978.47.1.71

Feltz, D. L., Chase, M. A., Moritz, S. E. \& Sullivan, P. J. (1999). A conceptual model of coaching efficacy: Preliminary investigation and instrument development. Journal of Educational Psychology, 91(4), 765-776.

https://doi.org/10.1037/0022-0663.91.4.765

Feltz, D. L., Short, E. S., \& Sullivan, P. J. (2008). Self-Efficacy in Sport, Human Kinetics, United States of America.

Ghobadi, H., Rajabi, H., Farzad, B., Bayati, M., \& Jeffrey's, I. (2013). Anthropometry of world-class elite handball players according to the playing position: reports from men's handball world championship 2013. Journal of Human Kinetics, (39), 213-220. https://doi.org/10.2478/hukin-2013-0084

Gleeson, G. (1987). The Coach in Action, The National Coaching Foundation Introductory Study Pack 1White Line Press England. 7-29.

Hodges, L., \& Carron, A. (1992). Collective efficacy and group performance. International Journal of Sport Psychology, (23), 48-76. 
Hyo, J. L. (1992). Antrenör eğitimi ve seminer notları, Ankara

Karaalioğlu, Z. (2015). SPSS'de output analizi, İstanbul Ticaret Üniversitesi, Sosyal Bilimler Enstitüsü, İşletme Ana Bilim Dalı, İşletme Doktora Programı, İstanbul

Karanfilci, M., Kabak, B., Hamamcılar, O., \& Aslanoğlu, E. (2013) Taekwondo spor yaralanmaları ve çözüm önerileri, Gençlik ve Spor Bakanlığı Spor Genel Müdürlüğü, Sağlık İşleri Dairesi Başkanlığı, Ankara

Kim, J., Dattilo, J., \& Heo, J. (2011). Taekwondo participation as serious leisure for life satisfaction and health, Journal of Leisure Research, 43(4), 545-559. https://doi.org/10.1080/00222216.2011.11950249

Kim, Y. S. (1995). What is taekwondo the concept of taekwondo, WTF, summer, (35), 21-26.

Konter, E. (1996): Bir Lider Olarak Antrenör. Alfa Yayıncılık, İstanbul.

Konter, E. (2006). Sporda karşılaşma psikolojisi, Nobel Yayınevi, Ankara.

Kurian, M., Caterino, L. C., \& Kulhavy, R. W. (1993). Personality characteristics and duration of ata taekwon do training. Perceptual and Motor Skills, 76, 363-366. https://doi.org/10.2466/pms.1993.76.2.363

Lees, A., \& Shedden, J. (1987). The Coach in Action, The National Coaching Foundation Introductory Study Pack 4 White Line Press England. 1987, 7-24.

Mallett, C. J. (2007). Modeling the complexity of the coaching process: a commentary. International Journal of Sport Science and Coaching, 2(4), 407-409. https://doi.org/10.1260/174795407783359768

Nosanchuk, T. A. (1981). The way of the warrior: the effects of traditional martial arts training on aggressiveness. Human Relations, 34, 435-444. https://doi.org/10.1177/001872678103400601

Nosanchuk, T. A., \& McNeal, M. L. (1989). Examination of the effects of traditional and modern martial arts training on aggressiveness. Aggressive Behavior, 15, 153-159. https://doi.org/10.1002/1098-2337(1989)15:2<153::AID-AB2480150203>3.0.CO;2-V

Petrovic, K. (2017). The benefits of taekwondo training for undergraduate students: a phenomenological study, Societies, 7, 27. https://doi.org/10.3390/soc7030027

Rothpearl, A. (1980). Personality traits in martial artists: A descriptive approach. Perceptual and Motor Skills 50, 395-401. https://doi.org/10.2466/pms.1980.50.2.395

Salman, M, N. (2012). Sporcuların antrenör yeterlilikleri değerlendirmesi anket çalışması, Aksaray University

Skelton, D. L., Glynn, M. A., \& Berta, S. M. (1991). Aggressive behavior as a function of taekwon do ranking. Perceptual and Motor Skills, 72, 179-182. https://doi.org/10.2466/pms.1991.72.1.179

Sports Statistics. (2019). http://sgm.gsb.gov.tr/Sayfalar/175/105/Istatistikler

Tadesse, E. M. (2016). Benefits and challenges of practicing taekwondo to adolescents in Addis Ababa City, Ethiopia, Revista de Artes Marciales Asiatic as, 11(1), 1-17. Enero Junior. https://doi.org/10.18002/rama.v11i1.3310

Toros, T., \& Duvan, A. (2011). Eskrimcilerde algılanan antrenörlük davranışı kolektif yeterlik ve hedef yönelimleri arasındaki ilişki, Niğde Üniversitesi Beden Ë̆itimi ve Spor Bilimleri Dergisi, 5(1), 34-41.

Türkmen, M. (2004). Uzakdoğu sporlarının (UDS) çocuk gelişimine etkisi, Sakarya Eğitim Fakültesi Dergisi, Ekim, (8), $562-582$

World Taekwondo Federation. (1995.) Taekwondo as an official Olympic sport and our responsibilities, Spring, No: 54, 2.

Yurt, O. (2009). Taekwondo antrenörlerinin liderlik tarzları, Selçuk Üniversitesi, Sağlık Bilimleri Enstitüsü, Yayınlanmamış Yüksek Lisans Tezi, Konya

Ziv, G., \& Lidor, R. (2009). Physical characteristics, physiological attributes and on court performances of handball players: a review, European Journal of Sport Science, 9(6), 375-386. https://doi.org/10.1080/17461390903038470

\section{Copyrights}

Copyright for this article is retained by the author(s), with first publication rights granted to the journal.

This is an open-access article distributed under the terms and conditions of the Creative Commons Attribution license which permits unrestricted use, distribution, and reproduction in any medium, provided the original work is properly cited. 